Взятие биопсии щитовидной железы, узлов, кист - 600-700 рублей в государственных учреждениях

Прием врача эндокринолога в частной клинике в Кирове и развитых городах области обойдется в 700-1000 рублей в зависимости от квалификации врача.

Можно сделать вывод о том, что диагностика заболеваний щитовидной железы довольно доступна, распространена как в государственных учреждениях, так и в частных клиниках.

Лечение:

Препараты ( г. Киров) L-тироксин 100-150 р Йодомарин 171,8p Эутирокс 160,30p Тирозол $155 \mathrm{p}$ Тирео-вит $225 \mathrm{p}$

Оперативное лечение при удалении узлов щитовидной железы, удалении опухоли, кист проводится в государственных учреждениях в порядке очереди на бюджетной основе в КОГБУЗ КОКОД: тиреоидэктомия-9000p, паратиреоидэктомия5250 p, субтотальная резекция щитовидной железы$6050 \mathrm{p}$.

Для восполнения недостатка йода в питании используются методы индивидуальной, групповой и массовой профилактики: ПРОФИЛАКТИКА

Чтобы избежать проблем со щитовидной железой:

- Нужно проходить профилактические обследования;

- заменить обычную соль на йодированную;

- включить в рацион морепродукты и другие продукты с содержанием йода: виноград, говядину, овёс, яйца, морскую капусту;

- необходимо отказаться от курения: научно доказано, что у курильщиков чаще встречается увеличенная щитовидная железа и тиреотоксический 30б;

Рациональное питание, использование обогащенных йодом пищевых продуктов и применение по показаниям и под наблюдением врача йодсодержащих лекарственных препаратов - триада комплексного решения проблемы йододефицита

\section{Выводы}

Мы оценили статистические данные по заболеваемости щитовидной железы на примере Кировской области за 2015-2017 г и выявили следующие закономерности: Кировская область - это район, где дефицит йода является острой проблемой и вследствие этого имеется высокая тенденция к развитию патологий эндокринной системы, в частности щитовидной железы. С каждым годом рост заболеваемости данного органа увеличивается, чаще всего регистрируются случаи заболеваний среди детей, подростков и женщин. Также мы отметили, что диагностика в Кировской области хорошо развита, но люди зачастую обращаются слишком поздно за помощью, т к течение заболевания часто бессимптомно. Вследствие этого приходится прибегать к крайним мерам- удалению щитовидной железы.

В рамках выполнения п. 4 Постановления № 1119 «О мерах по профилактике заболеваний, связанных с дефицитом йода» [Отчет Министерства здравоохранения РФ, 2001] совместным приказом Министерства здравоохранения и президента Российской академии медицинских наук № 185/37 от 30.05.2000 г. на базе ЭНЦ РАМН создан Центр по йоддефицитным заболеваниям МЗ РФ. Основными задачами Центра являются координация мониторинга йоддефицитных заболеваний щитовидной железы в регионах России.

\section{Список литературы:}

1.Государственный доклад «О состоянии санитарно-эпидемиологического благополучия населения в Кировской области в 2017 году»

2.Научная статья «заболевания щитовидной железы» 2017г. Глушаков Р.И., Козырко Е.В., Соболев И.В.

3.Постановление № 1119 «О мерах по профилактике заболеваний, связанных с дефицитом йода» [Отчет Министерства здравоохранения РФ, 2001].

4.Распоряжение от 31.07.12 № 1038 «Об организации медицинской помощи больным с эндокринными заболеваниями на территории Кировской области»

\title{
HEALING PROPERTIES OF INHALATION RADON OF TSKHALTUBO WATER ON THE PERIODONTITIS
}

\section{PhD student. David Aghmashenebeli University of Georgia. Dental Clinic Nikolaishvili, Marine \\ Professor and Heard of Department \\ I. Beritashvili Center of Experimental Biomedicine \\ Shishniashvili.Tamar \\ PhD. Tbilisi State Medical University \\ Museliani Tea \\ PhD I. Beritashvili Center of Experimental Biomedicine \\ Jikia Gogi \\ PhD I. Beritashvili Center of Experimental Biomedicine DOI: 10.31618/ESU.2413-9335.2018.4.57.30-36}

ABSTRACT: Inhalations with Tskaltubo water and its usage as a rinser, causes the decrease and afterwards elimination of the imflammatory processes of periodontium. This can be explained by the unique properties of Tskaltubo water. As we have seen, the above biochemical indicators in patients with periodontitis are the determinants of periodontitis. They are markers of periodontitis quality and we have clearly seen the huge effect of radon 
in the water of Tskaltubo, normalizing the action of oral cavity, slowing down the oral cervical inflammatory processes and eventually extinguishing them. These unique qualities have become the indicators of the treatment stimulating process and the process of preventing initial stage of periodontitis.

Key words: Tskaltubo mineral water, oral cavity mineralization.

Saliva as natural biological environment plays an important role in the vital capacity of teeth and periodontium. It maintains the oral cervical homeostasis. Normal functioning of salivary glands and permanent flow of saliva helps with intensive cleaning of oral cavity: from food waste, the waste from the metabolic processes between teeth tissue and mucous membrane. Reduction of salinity is an undesirable factor since it causes caries to develop [1]. The neutrophil elastase activity sharply increases in the patients with periodontium inflammatory processes what reflects the severity of the illness. The oral cervical protective function is performed by lysozyme, lactoperoxidase, secretive immunoglobulin, and other biologically active substances, which are generated by salivary glands [2,3] Electrochemical processes in the oral cavity are very important in the oral cavity diagnostic surveys. Function of mineralization of salivary glands is one of the main functions of this body organ. This is a complex biological fluid that carries out mineralization of the teeth and creates optimal conditions for their functioning $[4,5]$.

The basis of mineralization of saliva is a variety of functions, with the help of which dynamic equilibrium between the enamel and the saliva occurs. It corrects two processes: the solubility of the crystals of the enamel hydroxyapatite and their origin. Hydroxyapatite itself is the main dense compound of calcium and phosphorus, which occurs during physiological processes [1].

Only a daily capacity affects the content of saliva. The most intensive mineralization of saliva occurs between 10 and 120 'clock in the morning. However, the concentration of calcium and phosphorus, ionic strength of saliva and $\mathrm{pH}$ play the most important role in the evaluation of saliva mineralization and demineralization. In principle it is assumed that along with other factors in the development of multiple caries, there is a significant reduction in salinity. In order to keep homeostasis of the tooth tissue for the whole day, it is an important to maintain the constant level of calcium and phosphorus secretion all day long $[4,5]$. The average amount of calcium is $0.04-0,08 \mathrm{~g} / \mathrm{l}$, and phosphorus $0,06-0,24 \mathrm{~g} / \mathrm{l}$. The saliva $\mathrm{pH}$ is constant subject of interest among scientists and it is considered that acid medium of the oral cavity is the cause of caries. The effects of the enamel demineralization are observed at $\mathrm{pH}-6,0$ (average saliva $\mathrm{pH}-6,6-7,5$ ). Saliva usually has a neutral reaction. Very often there is a local reduction of $\mathrm{pH}$, which occurs due to microbes' attack on certain parts of the teeth, which has pathogenetic significance. As it is known, formation of dental tartar depends on the change of oral cavity fluid. At the beginning, the area around the tooth is attacked. This is going through 3 stages. First, amorphous non-bacterial cover is formed on the enamel cuticle, and then the microorganisms penetrate into the cover which spread in small colonies in the enamel defects. Their reproduction and the formation of calcium salts in the conglomerates launch the process of the formation of dental plaque [2]. The expressive cariogenic activity is carried out by candida fungus in the oral cavity [6]. It is believed that microorganisms from salivary urea form ammonia, which results in $\mathrm{pH}$-growth and calcium phosphate accumulation. Preparation of dental plaque is preceded by the increase of an apical dental outgrowth. The mineralization of this outgrowth is performed by diffusion of mineral salts of inflammatory exudation. Dental plaque leads to the local intoxication of the gingiva and deepens the inflammation process. The surface of the dental plaque is covered with a mixture of microbes, which is still negatively affects the periodontium tissue. All of this goes on and reaches the root of the tooth, which continuously interacts with soft tissues surrounding the tooth. Ferments (hyaloronidasa, collagenase, chondroitin sulphatase), microbes endo-, exo- and chemotaxins, which are the products of bacterial metabolism, including biogenic amines, produced in the result of the death of the periodontium cells - allergens $[10,11]$. The active factor of protein is found in this layer which is acting on the vascular patency of the periodontium tissue. Long-lasting action on the teeth of all the above factors causes chain process of autoimmune reactions that leads to periodontium tissue alternative changes. In order to maintain the oral cervical homeostasis, it is important to have over-saturation of hydroxyapatites, which indicates to the ability of saliva to maintain the homeostasis of tooth tissue. In order to make this happen, it is very important to use Tskaltubo water in inhalations and rinsing. The alpha radiation of radon in Tskaltubo water has a great significance in regulating the inflammatory process and maintaining the oral cavity homeostasis. As it is known, resent publications $[11,13]$ denied carcinogenic effects of small doses of radiation caused by radon therapy and, on the contrary, showed that this dose is characteristic of the socalled "hormesis", therefore, our interest is to determine the mechanism of radon hormesis and its application to maintain the mineral metabolism of the oral cavity $[16,17]$. Radon mainly has $\alpha$-radiation, because of which the treatment with radon water is called alpha therapy. The radiation of Tskaltubo mineral water varies by $1 \mathrm{ng} / \mathrm{l}$, approximately $37 \mathrm{~Bq} / \mathrm{m}^{3}$ (12). Radon therapy has a strongly marked analgesic effect on the inflammatory processes occuring in the nervous tissue. It accelerates the regeneration of nervous tissue and nerve fibers $[12,18]$. Tskaltubo mineral water is of a large debit and is considered as chloride-hydrocarbonate-sulfate-magnesium-calcium-sodium water $[14,19]$. It is characterized by stability and does not change with the time. There are following microelements in water: iodine, bromium, magnesium, lithium, zinc, strontium, copper, the amount of which is low, but their significance rises during inhalations. Due to this, the uniqueness of Tskaltubo water and the mechanism of radon 
effect is very important and requires considerable study $[13,20]$.

Therefore, our main goal is to study biochemical indicators of the oral cavity during radon therapy: the total protein, amylase, lactadehydrogenase, glucose quantity, $\mathrm{Ca}$ and $\mathrm{P}$ mineral metabolism, $\mathrm{pH}$ increase or decrease, and periodontium index change, which causes development of inflammation processes in oral cavity. These are the factors that define the disease,

These are the factors that define the disease, they are quality markers of periodontitis and we have clearly seen the high efficiency of radon in the water of Tskaltubo on the balance of oral mineralization, neutralization of saliva $\mathrm{pH}$, normalization of the enzymes, slowing down the inflammatory processes and eventually extinguishing them. These unique features of radon have become the catalyst of the treatment and blocker of initial phase of periodontitis [17].

Periodontitis is a disease of the tissues around the tooth, during which the tooth-gingival link is broken. The pathological process gradually damages tooth socket, along with this a tooth loses its bone support and it starts loosening. Today every third person has periodontitis of some kind. Periodontitis is caused by different factors. The reasons for this includes: deformed dentition, deviation of occlusion, incorrect load on masticatory teeth, improper hygiene of the oral cavity, incorrect dietary supplements, particularly deficiency of proteins and vitamins [1.2].

Without treatment after a definite period of time the jaw bone loss occurs, what causes changes in the dentition and developing of space between teeth. Antiinflammatory treatment is carried out to restore blood normal microcirculation in the periodontium tissues, in which the main role belongs to the medicinal therapy $[3,5]$. Physical therapy procedures are also performed during local treatment, including vitamins, mainly $\mathrm{C}$ and B group. Physical therapy procedures are also performed during local treatment, prescribed vitamins, mainly $\mathrm{C}$ and $\mathrm{B}$ group. Based on the above, our main aim was to study the effect of radon inhalations and rinsing with Tskaltubo water on the oral mineralization of the oral cavity. Radon is characterized by: antiseptic, antioxidant, anti-inflammatory, cito-protective, properties of cellulite; it retains anti-cellulite properties, preserves elasticity of the blood vessels, prevents the development of aterosclerosis, reduces the risk of cardiovascular diseases. It has regenerative properties and is used in the mild and moderate forms of gingivitis and periodontitis [15]. It is known that in recent years the application of new, high therapeutic and preventive properties is preferable, so the purpose of our observation was to study complex effects of modulating effects of radon in Tskaltubo water in patients with periodontitis.

\section{Materials and methods \\ Oral cavity hygienic condition}

According to the method of Fidorov-Volodkina (Федоров Ю.А., Володкина В.В.), the oral hygienic condition of the oral cavity is as follows: vestibular surfaces of teeth 31, 32, 33 are colored with SchillerPisarev, Lugell or other paintings. The dyed surface of the tooth crown is measured in a 5-point system: $1-$ no coloration; 2 - coloration of $1 / 4$ of the tooth crown;

3 - coloration of $1 / 2$ of the tooth crown; 4 - coloration of $3 / 4$ of the tooth crown;

5 - coloration of the entire surface of the tooth crown.

Hygiene Index Formula: Nh. med $=\Sigma / 6$, where $\Sigma$ - the sum of the points of all the 6 teeth;

The hygiene level of the oral cavity is determined according to the $\mathrm{Nh}$ results of all the 6 studied teeth: 1,1-1,5 points - good level of hygiene; $1,6-2,0$ points satisfactory; 2,1-2,5 points - unsatisfactory; 2,6-3,4 points - bad; 3,5-5.0 points - very bad. The hygienic indexes of Fidorov-Volodkina cannot have more than 5 and less than 1 point value.

2.2 Periodontitis Index determination: Detection of periodontitis has a very high importance for determining the level of inflammatory processes. The level of periodontitis is determined for each tooth.

Then the level of periodontitis is calculated according to the formula:

\section{Total rating}

$\mathbf{P i}=$

The number of teeth

Interpretation of the Index: 0,1-1,5 initial form of periodontitis stage 1 ; stage 2 of periodontitis - 1,5 2,5 ; stage 3 of periodontitis - 2,5-4; stage 4 of periodontitis - 4-8.0.

PMA. We estimate the spread of inflammatory changes in parodont tissues by the Papillar-Marginal Alveolian Index (Parma, 1960) modification.

In order to determine it we colored the vestibular surfaces of the gingival with iodine-containing solution and determined the condition for each tooth - gingival papillae, free (marginal) and attached (alveolar) gingival areas. Inflammatory areas became dark brown.

Gingival inflammation level assessment codes:

0 - absence of inflammation;

1 - Inflammation of the gingival papillae;

2 - Inflammation of papillae and marginal gingiva;

3 - Inflammation of papillae, marginal gingiva and alveolar gingiva.

The calculation formula for index value (2)

Sum of the codes

PMA =

$3 *$ Number of teeth

Interpretation of the indexes:

Index value - Index of gingivitis inflammation

Less than $30 \% \quad$ - mild

31-60\% - moderate

The treatment of chronic generalized periodontitis was based on the individual approach to each patient, taking into consideration its general condition and dental status. With regard to the fact that the issue of periodontitis ethiology is not yet fully studied, periodontitis treatment was carried out using the inhalation and rinsing with Tskaltubo radon water. Within 10 days.

Complex research has been conducted to identify the processes in the gingival of all the patients. The patients with periodontitis were divided into two groups according to the level of periodontitis. 60 patients with $1.3 \mathrm{~mm}$ deep parodontic pockets were conditionally en- 
listed into the group with mild periodontitis, and patients who had $4 \mathrm{~mm}$ deep pockets were placed in the group with moderate periodontitis (60 patients). After that, we divided our patients into another two groups (30 patients who had been treated with Tskaltubo water inhalations and 30 patients who had been treated with Tskaltubo water inhalations and rinsing twice a day after meals in the morning and evening.(1)

1. PH Determination: Various indicators are used to determine the base - alkali of the oral cavity. The exact, quick and easy method is the so called Potential meteoric method for which they use arrowpointer or digital laboratory $\mathrm{pH}$ meter that is equipped with a highly sensitive power line towards hydrogen ions, and another auxiliary electrode. Also, there was a $\mathrm{pH}$ determination on the indicator paper. Main principle of the method is the change of the physic-chemical properties of paper indicator paper. Change of the saliva color on the indicator paper (after dropping) is compared with $\mathrm{pH}$-corresponding scales (2).

2. Mineralization of saliva. Mineralization of saliva is of great importance in maintaining oral cavity mineralization. The saliva is a calcium and phosphorus solution which is the basis for its mineralization. The mineralization of saliva causes calcium and phosphorus to spread their diffusion from the mouth to the tooth enamel, thus strengthening and increasing the tooth structure, as it continuously enhances the enamel and increase the tooth strength with age [4].

3. Determination of calcium. The principle of calcium determination is based on the formation of a complex between the calcium ion and the EDTA-ion that is resistant to strong alkaline reaction. In this area of $\mathrm{pH}-12-13$, the magnesium ions are dissolved in the form of hydroxide. The absence of free calcium is approved by Trilon B-titration in the coordination of the indicator murexide [6].

Testing: $0.5-1.0 \mathrm{ml}$ of saliva dissolves in $50 \mathrm{ml}$ of distilled solution; $1 \%$ hydrochloride hydrochloride, 1 $\mathrm{ml}$ and $2 \mathrm{ml}$ nitrogen sodium hydroxide, some of the murexine crystals are added and then are rotated until
0,05 Trilon B color change. Lower limit of calcium detection is $0.5 \mathrm{ml}$ saliva is $8.0 \mathrm{mg} / 1$ [7].

4. Determination of phosphorus. This method is based on the ammonium phosphate reaction in the acidic area with the ammonium molybdate resulting in a yellow color heteropolymic acid, which ascorbic acid restores and transforms into a compound formation [9].

Testing: To $1 \mathrm{ml}$ saliva is added to $2,4 \mathrm{ml} 7 \%$ TXY, and centrifuged. The supernatant of the solution (0.1-2.0 ml)is used for analyses. Color intensity is determined by the spectrophotometer. The lower threshold of phosphorus is $1 \mathrm{mg} / 1$.

\section{Results and their review.}

In the examined contingency we have studied, evaluated and analyzed a complex effect of sociohygienic and medico-biological factors on caries formation. In clinically examined adults, socialhygienic factors have shown that the abuse of refined carbohydrates has a relatively adverse effect on caries. The comparison of the researched groups showed that the frequency of use of sugar, bread and candies (confectionery) and confectionery products is high. Compared to the patients with caries and confectionery groups it was found that their consumption is significantly higher among patients with caries than in the healthy $(78.8 \%$, in the patients with caries and $2,9 \%, 6.5 \%$ and $11,8 \%$ respectively - in confectionery groups).

As a result of assessment of the information received from the questionnaire and the oral cavity assessment result, the data on important social-hygienic factors, such as the rheumatoid arthritis and the cause of oral hygiene, was received.

The condition of oral hygiene, according to mathematical and statistical analysis, was estimated in the 30-35 age groups according to the quality of caries activity.

From Table 1 it becomes clear that the oral hygienic condition in the study group is not satisfactory. The indicator is much more common in a group of caries, compared to the control group

Table1.

The oral cavity hygiene condition according to the examined groups

\begin{tabular}{|c|c|c|c|c|c|c|}
\hline Examined group & $\begin{array}{c}\text { Oral } \\
\mathrm{HI}=1,1-1,5\end{array}$ & $\begin{array}{c}\text { Cavity } \\
\mathrm{HI}=1,6-2,0\end{array}$ & $\begin{array}{c}\text { hygiene } \\
\mathrm{HI}=2,1-2,5\end{array}$ & $\begin{array}{c}\text { index } \\
\mathrm{HI}=2,6-3,4\end{array}$ & $\mathrm{HI}=3,5-5,0$ & total \\
\hline caries & 10 & 15 & 25 & 40 & 55 & 145 \\
\hline & $6,9 \%$ & $10,34 \%$ & $17,24 \%$ & $27,6 \%$ & $38 \%$ & 100,0 \\
\hline & $0,6 \%$ & $0,10 \%$ & $0,17 \%$ & $2,8 \%$ & $3,8 \%$ & $6,8 \%$ \\
\hline
\end{tabular}

The table shows that the hygienic index is high in almost every group (I, II, and III degree). According to the regularity of visits to a doctor-dentist, just 8,9\% performed them, out of the whole number of participants. $6,8 \%$ out of them had caries.

As a result of studying the questionnaire of patients, we decided to examine the use of Tskaltubo water as the evening inhalations, as the evening rinsing its effective influence on the patients. Table 2 shows that the index of mild and moderate forms of periodontitis has increased in the index, which indicates the development of inflammatory process and damage to tissue. If we use Tskaltubo water, we can see how this process gradually slows down and then return within the norm. Use of Tskaltubo water has shown the improvement of the periodontitis index and slowing down of the inflammatory process. In later experiments we were exploring mineralization of saliva and partly biochemical changes. From the literature (), it is known that they determine the quality of the periodontitis. Clinical studies have shown that in patients with periodontitis there are some changes in the oral cavity fluid expressed in $\mathrm{Ca}$ and $\mathrm{P}$ microscopic shifts, as shown in Table 2, patients with mild and moderate forms of periodontitis have some changes in Ca's shifts, namely, calcium is increased. If in control it was $-1,97 \pm 0.65$, while mild 
forms the increase was observed - 2,45 $\pm 0,05$, and in moderate form it increased by $2,48 \pm 0,17$. As a result of two-week treatment, these changes will return to the norm. Similar expression is also observed on the P's

shift. In the control it is $0,22 \pm 0,03$, while in mild form it is $0,18 \pm 0,06$, in the case of moderate one $-0.15 \pm$ 0,01 and after treatment it returns to the norm.

Table 2.

Use of Tskaltubo water for inhalations and rinsing and its effect of oral cavity mineralization change and $\mathrm{pH}$ acidity - alkalinity

\begin{tabular}{|c|c|c|c|c|c|c|}
\hline \multirow[t]{2}{*}{ Index } & \multicolumn{2}{|c|}{ Mild form } & \multicolumn{2}{|c|}{ Moderate form } & control & control \\
\hline & $\begin{array}{c}\text { Inhalation } \\
\text { with } \\
\text { Tskaltubo } \\
\text { water }\end{array}$ & $\begin{array}{l}\text { Inhalation } \\
\text { and rinsing }\end{array}$ & $\begin{array}{c}\text { Inhalation } \\
\text { with } \\
\text { Tskaltubo } \\
\text { water }\end{array}$ & $\begin{array}{l}\text { Inhalation } \\
\text { and rinsing }\end{array}$ & $\begin{array}{c}\text { Inhalation } \\
\text { with } \\
\text { Tskaltubo } \\
\text { water }\end{array}$ & $\begin{array}{l}\text { Inhalation } \\
\text { and rinsing }\end{array}$ \\
\hline $\mathrm{Ca}$ - change & $2,45 \pm 0,05$ & $\begin{array}{c}2,15 \pm 0,02 \\
\mathrm{P}<0,05\end{array}$ & $2,49 \pm 0,17$ & $\begin{array}{c}2,27 \pm 0,07 \\
\mathrm{P}<0,05\end{array}$ & $1,97 \pm 0,65$ & $\begin{array}{c}1,90 \pm 0,65 \\
\mathrm{P}>0,05\end{array}$ \\
\hline $\mathrm{P}$ - change & $0,16 \pm 0,06$ & $\begin{array}{c}0,18 \pm 0,03 \\
\mathrm{P}>0,05\end{array}$ & $0,15 \pm 0,01$ & $\begin{array}{c}0,19 \pm 0,05 \\
\mathrm{P}<0,05\end{array}$ & $0,23 \pm 0,03$ & $\begin{array}{c}0,24 \pm 0,02 \\
\mathrm{P}>0,05\end{array}$ \\
\hline $\begin{array}{c}\text { pH acidity - } \\
\text { alkalinity }\end{array}$ & $\mathrm{pH}-6,2$ & $\begin{array}{l}\mathrm{pH}-6,4 \\
\mathrm{P}<0,05\end{array}$ & $\mathrm{pH}-6,0$ & $\begin{array}{l}\mathrm{pH}-6,4 \\
\mathrm{P}<0,05\end{array}$ & $\mathrm{pH}-6,5$ & $\begin{array}{l}\mathrm{pH}-7,0 \\
\mathrm{P}>0,05\end{array}$ \\
\hline
\end{tabular}

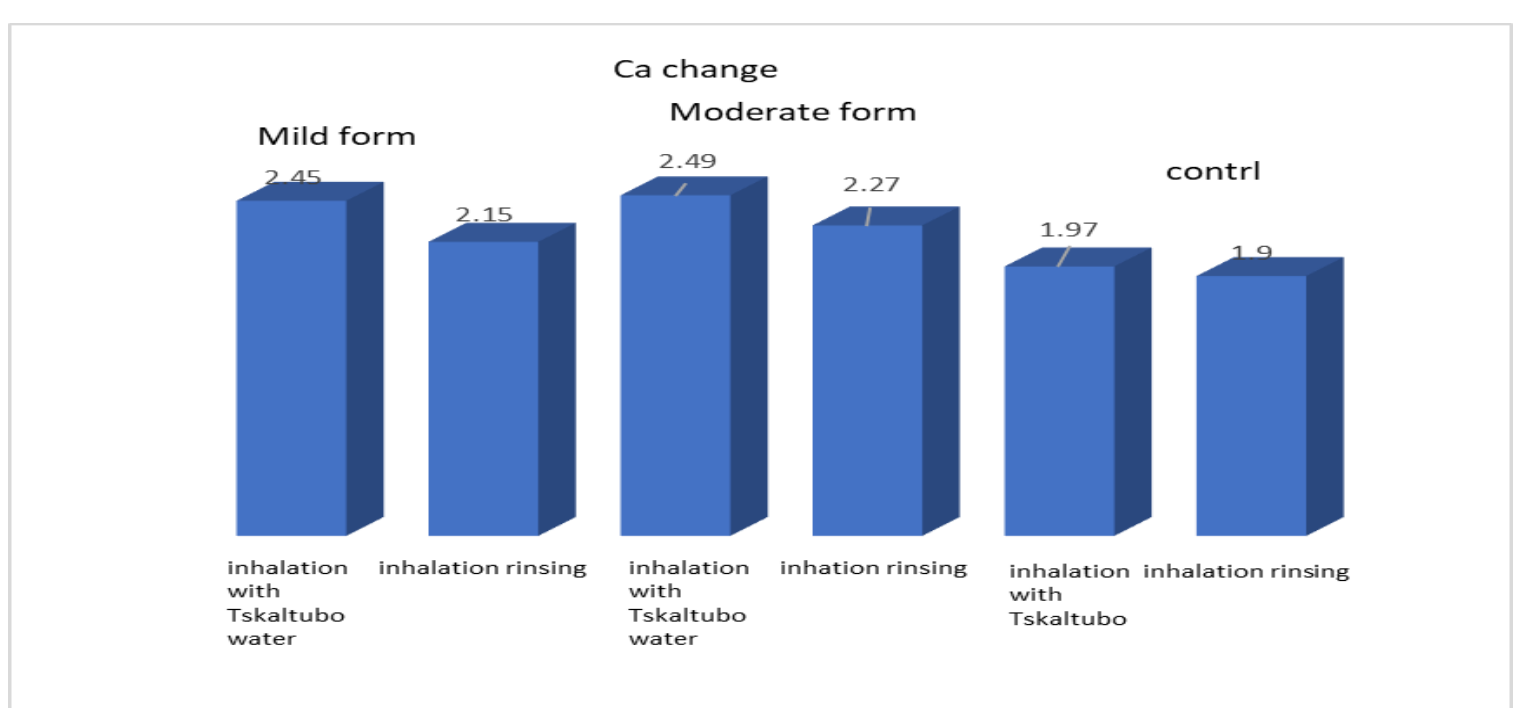

Fig.1 Use of Tskaltubo water for inhalations and rinsing and its effect of oral cavity Ca change

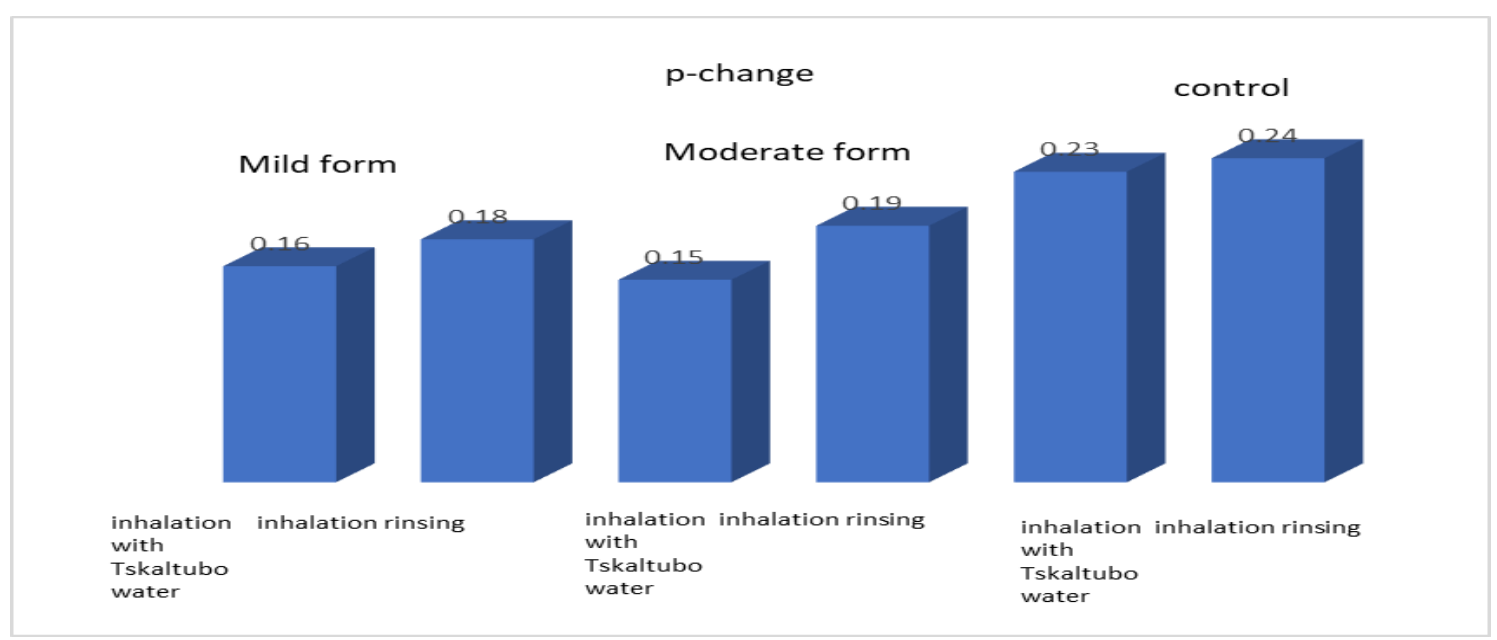

Fig.2 Use of Tskaltubo water for inhalations and rinsing and its effect of oral cavity p-change 




Fig.3 Use of Tskaltubo water for inhalations and rinsing and its effect of oral cavity $\mathrm{pH}$-acidity

Thus, we can conclude that the use of Tskaltubo water and in inhalations and its use as a rinsing eventually cause a slow reduction of the inflammatory process in the case of periodontitis and eventually extinguishing. This can be explained by the unique features characteristic for Tskaltubo water. As we have seen, the biochemical indicators shown in patients with periodontitis are the markers of periodontitis forms and we have clearly seen the high efficiency of radon in the water of Tskaltubo, normalization of the oral cavity enzymes, slowing down the oral inflammatory processes and eventually extinguishing. These unique qualities have become a treatment stimulating and the blocker of the initial stage of periodontitis.

\section{Bibliograpy}

1. Iverieli M, Abashidze N. Pharmacotherapy of Parodontist Diseases // TB, 1998.

2. The clinical bacteriology on the kerosel. 'Euro', Tbilisi, 2001

3. Nemsadze O, Amiridze Z, Parodontist Diseases // Tb, 1989.

4. Nikolaishvili M., Tamazidze N., Mosemghvdvlishvili N, Lizocyclide Index Research in mixed saliva, patients with non-reconciliation technique at orthodontic treatment stage. G.experimental and clinical medicine. N2, 41-45, 2015.

5. Nikolaishvili, Tamasidze N., Mosemgdvlishvili, Evaluation of the position of local immunity of the oral cavity and secreter immunoglobulin LGA, quantitative contents in patients with orthodontic treatment.Experimental and clinical medicine. N2, 53-56, 2015.

6. Shishniashvili T. Prophylaxis for Dental Diseases. Tbilisi 2004

7. Алимова, Р.Г. Гигиена полости рта и современная ортодонтия / Р.Г. Алимова, С.Н. Махсудов // Stomatologiya (Ташкент). - 2004. - № 1-2. C.102-106.

8. Григорьян, А.С. Микроорганизмы в заболеваниях пародонта: экология, патогенез, диагностика / А.С. Григорьян, С.Ю. Рахметова, Н.В. Зырянова. - М.: ГЭОТАР-Медиа, 2007. - 56 с.
9. Грудянов, А.И. Методы диагностики воспалительных заболеваний пародонта: руководство для врачей / А.И. Грудянов, О.А. Зорина. - М.: МИА, 2009. - 112 c.

10. Картон, Е.А. Механизмы регуляции микроциркуляции в тканях пародонта у зубов, используемых для анкоража при ортодонтическом лечении / Е.А. Картон, Н.В. Снеткова, С.Н. Ермольев, Ж.А. Ленденгольц // Ортодонтия. - 2013. - № 1. - С.5659.

11. Buldakov L.A. Radiation influence on the body-positive effects/ Buldakov L.A. Kalistratova B. S.-2005

12. GelashviliGK, Vefxvadze N, Xazaradze R at all. Current radiation safety issues in Georgia. 1 National Conference 2001. Tbilisi pp 146-156.

13. Harkin LA, McMahon JM, Iona X. The spectrum of SCN1A-related infantile epileptic encephalopathies. Brain. 2007; 130: 843-852.

14. Kuzin A.M. Radiation hormesis in immunology.//immune status and radiaion: Tethis of USSR Scientific Kalistratova B.S., Nisimov P.G. Extrapolation of experimental data on late effects of low dose radionuclides in man //Low doses of ionizing radiation biological effects and regulatory control. International Conference held in Seville, Spain, 17-21 November, 1997. IAEA. 1997. PP. 395-397.

15. Khazaradze K. P. Khazaradze P.E. Amiraznashvili A. E. Bliadze T. A. Nodia A. B. Nikiphorov G. I. Chelidze L. D. Some results of the research of radon contents in the human environment /The $1^{\text {st }}$ international conference in Ecology and management of Caucasus environment. /Tbilisi 2001, PP61-63

16. Luckey T. D. Radiation hormesis: the good, the bad, and the ugly. Dose Response. 2006;4(3):16990

17. Mitsunobu F., Yamaoka K., Hanamoto K., Kojima S.,Hosaki Y., Ashida K.,Sugita K.,Tanizaki Y. Elevation of antioxidant enzymes in the clinical effects of radon and thermal therapy for bronchial asthma //J. Radiat.Res. 2003. V. 44. P. 95-99. 
18. Reo Etani, Takahiro Kataoka, Norie Kanzaki, Akihiro Sakoda, Hiroshi Tanaka, Yuu Ishimori, Fumihiro Mitsunobu, and Kiyonori Yamaoka. Difference in the action mechanism of radon inhalation and radon hot spring water drinking in suppression of hyperuricemia in miceJ Radiat Res. 2016 Jun; 57(3): 250-257
19. Nikolaishvili M.I. Tamasidze A, Gyu Results of biochemical studies in the treatment of radon patients Georgian Medical News, Tbilisi, 2006,N12, (141) 91-93,

20. Neifakh E.A. Large radio-pathogenic loads of children from "small doses" of technogenic chronic radiation // Radiation Biology. Radioecology. 2003. P. 43, No. 2. P. 193-196ю

\section{ОПРЕДЕЛЕНИЕ СРЕДНИХ РАЗМЕРОВ ПОЧКИ ДЛЯ ПОСЛЕДУЮЩЕГО СОЗДАНИЯ НА ИХ ОСНОВЕ 3D-МОДЕЛИ.}

Поздеев Дмитрий Алексеевич

Студент 6 курса лечебный факультет,

ФГБОУ ВО «Ижевская государственная медицинская академия»

МЗ РФ, г. Ижевск

Варганов Михаил Владимирович

Доцент, д.м.н., профессор кафедры факультетской хирургии ФГБОУ ВО «Ижевская государственная медииинская академия»

МЗ РФ, г. Ижевск

DOI: $10.31618 /$ ESU.2413-9335.2018.4.57.36-37

АННОТАЦИЯ:Целью исследования было определение средних размеров почек, наиболее часто встречающихся на территории Удмуртской Республики, для последующего создания на их основе 3D-модели. При проведении исследования методом случайной выборки был произведен отбор историй болезни пациентов урологического отделения БУЗ УР «1РКБ МЗ УР», с последующей обработкой данных. В ходе исследования получены результаты о средних размерах почек на территории Удмуртской Республики.

ABSTRACT:The aim of the study was to determine the average size of the kidneys, most commonly found on the territory of the Udmurt Republic, for the subsequent creation of a 3D model based on them. When conducting a random sampling study, a selection of case histories of patients of the urological department of the SHI UR "1RKB MoH UR" was made, followed by data processing. The study obtained results on the average size of the kidneys on the territory of the Udmurt Republic.

Ключевые слова: 3D-модель, средний размер почек, мочекаменная болезнь

Key words: 3D-model, average size of kidneys, kidney stone disease

Актуальность. В настоящее время в Российской Федерации существует проблема роста заболеваемости мочекаменной болезнью, к тому же Удмуртская Республика является регионом эндемичным по данному заболеванию. К примеру, на долю МКБ в структуре первичной заболеваемости по РФ приходится $0,16 \%$, а в ПФО - 0,17\%, на долю МКБ в структуре общей заболеваемости в РФ приходится $0,33 \%$, а в ПФО - 0,29\%. Первичная заболеваемость населения МКБ выросла как в РФ и ПФО: в 2016 г. первичная заболеваемость МКБ в РФ составляет 150,0 на 100 тыс. человек (на 4,4 \% больше к уровню 2012 года), в ПФО - 162,4 (рост на 6,8 $\%)[4]$.

Кроме непосредственно роста заболеваемости МКБ, наблюдается и рост частоты встречаемости коралловидных камней, представляющих собой камень повторяющий форму лоханки и заполняющий её, являющихся одной из тяжелых форм мочекаменной болезни с достаточно высоким уровнем летальности. И в данном случае чрескожная нефролитолапексия является наиболее современным и малоинвазивным методом, используемым в лечении пациентов с коралловидными камнями.

В настоящее время отсутствует возможность обучения будущих медицинских специалистов выполнению различных инвазивных вмешательств на почке, в том числе и чрескожную нефролитолапексию, кроме как непосредственно во время выполнения операции на почке и тренажерах, которые не отражают анатомо-топографические особенности почки и окружающих ее тканей и органов. И именно для решения этой проблемы будет создан тренажер на основе данных о средних размерах почки, также с помощью тренажера возможно выполнение и других пункционных вмешательств на почке.

Цель.

Целью исследования является определение средних размеров почки, на основании наиболее часто встречающихся на территории Удмуртской республики, для последующего создания 3D-модели почки на основе данных МРТ и СКТ.

\section{Материал и методы.}

Наш тренажер будет выполнен в виде участка тела, соответствующего расстоянию от Х грудного позвонка до копчика, что соответствует 33-35 см. В тренажере будут располагаться в соответствии с их топографо-анатомическим расположением модели органов созданные на основе наиболее часто встречающихся вариантов анатомии почки, мочеточника, мочевого пузыря. Данные модели будут получены на основе обработки историй болезни и сборе данных по размерам почки, полученных с помощью ультразвукового исследования, МРТ и СКТ почек, 